\title{
The Challenge to Critical Thinking Posed by Gender-Related and Learning Styles Research
}

\section{Neil Browne}

\section{Nancy K. Kubasek}

\section{Julie A. Harris}

Bowling Green State University

Recent national reports on the quality of higher education consistently rank the development of critical thinking skills as a primary objective for university curricula and instructors (Association of American Colleges, 1985; National Institute of Education, 1984). Rare indeed is a curricular reform that does not genuflect in the direction of improved critical thinking. Faculty too are often quick to pay allegiance to the importance of critical thinking for their classrooms. Fortunately, however, such movements typically generate thoughtful skepticism as a byproduct of their success.

Two streams of modern research threaten the popularity of critical thinking, particularly certain forms of critical thinking. This paper attempts to describe the nature and limits of this challenge. The first two sections describe specific criticisms of critical thinking; the final section attempts to respond to those criticisms. Our objective is to examine the extent to which gender-related and learning styles research programs demonstrate the inappropriateness of critical thinking instruction for certain students. 


\section{Gender-Related Research and Critical Thinking}

Moral development studies by Piaget, Kohlberg, and Erikson define development as movement toward autonomy and autonomous judgment. Women, however, tend to have much more tenaciously embedded relationships with others than do men and to develop a mode of judgement that is contextual. Thus, women are often perceived as deviant or deficient from the perspective of developmental models derived from male subjects (Gilligan, 1987). Developmental models based on male subjects may consequently be misleading for either descriptive or prescriptive purposes.

In an effort to rectify this problem, Carol Gilligan's In $A$ Different Voice (1982) presents a moral development model more appropriate for women. Gilligan's model focuses on notions of responsibility and care, in sharp contrast to the morality of rights developed by Kohlberg (1981) and Piaget (1948). According to this argument, just as previous studies of moral development concentrated almost exclusively on the developmental stages of men, conceptions of truth and knowledge have also been shaped throughout history by male-dominated majority culture (Belenky et al., 1986). Men have constructed the prevailing theories, written the history, and established the values that have become the guiding principles for both men and women.

This domination of developmental models by male perspectives has affected several disciplines. In sociology (Smith, 1974), history (Lerner, 1979), anthropology (Slocum, 1980), and other social sciences (Spender, 1981), women have been studied in terms of their deviance from the male norm, or have been subsumed by the male-biased research paradigm focusing on the pursuit of objectivity and the assumed gap between the knower and the object of study. Relatively little attention or value has been accorded to the modes of knowing, learning, and valuing that may be specific or common to women. Hence, an important objective of genderrelated research is to describe habits of mind common to women and to determine ways to approach these differences in the classroom.

At the forefront of such research is Women's Ways of Knowing (Belenky et al., 1986). This work is based on interviews with 135 women, 90 from colleges and 45 from family agencies that assist those seeking help with parenting. The women interviewed represented various class and ethnic backgrounds. A recurring theme of the interviews was the feeling of alienation many women experience in educational environments. A dearth of reinforcement and praise, cited in many interviews, often led these women to believe themselves incapable of intelligent thought. Feel- 
ings of self-doubt and intellectual inferiority are almost inescapable for many female students.

Exacerbating these feelings is the emphasis on abstract, non-contextual thought in higher education (Belenky et al., 1986). Personal experience and contextual knowledge provide the majority of these women with their most reliable sources of information. Many cited out-of-school incidents as their most educationally rewarding experiences, with childbearing and -rearing as oft-cited examples. While highly valued among women, however, these experiences often wield little clout in a university setting. Given their discomfort with abstract thought, many of the female interviewees actively resisted critical modes of analysis favored in the university. Many of them construed critical thinking as an adversarial activity and, therefore, found it uncomfortable and unrewarding. The majority of interviewees reported that they learned best by trying to understand others' positions (Clinchy, 1987).

This way of knowing frequently implies a personal relationship between the knower and the object to be known. The approach to research used by many feminist scholars reflects this emphasis on sharing. For example, in "A Feminist Research Ethos" (1988), Ann Bristow and Jody Esper contrast the male research approach of interrogating subjects with the feminist approach of conducting a dialogue with their subjects. In contrast to male researchers' attempts to remain aloof from the subjects of their studies, feminist researchers try to minimize the distance between themselves and those they are studying (Malhotra, 1988). The adversarial procedures that some women view as part of critical thinking are not conducive to forming the close relationships that female researchers seek with their interviewees or respondents.

In the study by Belenky et al., the subjects' disdain for what was defined as "critical thinking" extended beyond academic settings. Many commented that men are adversarial and combative even in casual conversation. The women in this study, on the other hand, reported a preference for conversations that were sharing and collaborative. Critical thinking, to these women, is synonymous with "male logic," a thought process they find adversarial, uncomfortable, and alienating.

Based on these interviews, the authors of Women's Ways of Knowing conclude that women prefer less critical modes of thought. They term critical, analytic thought processes "separate knowing," and suggest that "connected knowing" is a thought process more suited to women. Connected knowers are not aloof; unlike separate knowers, they attempt to "get behind the other person's eyes." Because connected knowing implies 
a relationship between the self and the subject or object of knowledge, most women feel quite comfortable with such a style of knowing.

In a conference at the University of Chicago, one of the book's authors, Blythe McVicker Clinchy, recommended that women be taught uncritical thinking: "I am saying that many women would rather think with someone than think against someone." Connected knowing's emphasis on acceptance over evaluation makes it an appropriate means to such an end (Clinchy, 1987).

Thus, the final recommendation of much of the gender-related research, particularly Women's Ways of Knowing, is for educators to emphasize connected knowing as acceptable and even desirable. By trying to see the world from the perspective of those being studied or evaluated, we are, according to this argument, better able to comprehend and accept. In contrast, forcing women to comply with fundamentally "male" ways of knowing, such as abstract, objective thought, may undermine women's sense of intellectual self-worth and ultimately alienate them from the educational process. These claims will be evaluated in the final section of this paper.

\section{Learning Styles Research and Critical Thinking}

Avoiding potential alienation in the classroom also provides much of the impetus for learning styles research. Most who tout the importance of learning styles recommend that learning and teaching styles be strategically matched for academic success. Matching entails identifying a student's learning style and then selecting a teaching style that complements it. This advice is based on the assamption that one must meet students where they are, not where the teacher might like them to be.

Scott G. Paris (1988), for instance, urges teachers to apply a model of instruction compatible with the students' learning model or metaphor. The key here is to create a match among the learner's task, context, and strategy so that the required actions fit into the learner's ongoing behavior. His rationale for advocating matching among educators and learners is to encourage students to employ their learning strategies with greater frequency, even when they are working independently of the instructor. Significantly, Paris notes that matching is desirable only when it reinforces a positive learning style.

Almost all research advocating the matching of learning and teaching styles claims that matching enhances performance on tests. To improve success in college, "college students ... should choose professors whose teaching styles complement their own learning styles" (Radebaugh et al., 
1988). The findings of Charkins et al. (1985) corroborate such research by concluding that achievement and attitude are positively affected by a matching strategy.

Efficiency is sometimes provided as a justification for matching. Students who are strategically matched with their professors require fewer iterative repetitions to master the material. In one study, matched students needed one to three repetitions, compared to four to seven repetitions required by mismatched students, to reach a particular level of mastery (Pask, 1988).

Other research promotes matching as an ideal way to cultivate selfconfidence in learners (Charkins et al., 1985; Claxton and Murrell, 1987; Paris, 1988). Poorly prepared students seem to benefit the most from this approach. When these learners are initially confronted with a confusing teaching style, they risk failure, which can discourage them and jeopardize their future academic success. Matching thus appears to facilitate their development primarily by affirming their sense of self-worth.

\section{Evaluating the Challenge to Critical Thinking}

\section{Gender-Related Research}

Both gender-related and learning styles research are very concerned with creating classrooms that engage rather than alienate learners. An educational approach based on male perspectives is inadequate for many female learners in most classrooms. Similarly, a learning style that addresses some students shortchanges other learners who could be matched with a more compatible style.

While we have much to learn from both gender-related and learning styles research, we should not exaggerate their implications. Research detailing differences in ways of knowing and learning styles is marvelously descriptive. Indeed, it reminds instructors that their students are not a monolithic glob. The bulk of this research, however, ultimately fails to offer educators a prescription for encouraging students to improve their ways of knowing or their learning styles.

Gender-related research, while undoubtedly intended to benefit women, contains the potential for ultimately harming them. If the recommendations of Blythe Clinchy are widely embraced, for example, necessary skills of analysis and evaluation may be taught to women in a cursory fashion. Sensitive instructors may hesitate to provide women critical feedback on a paper or an examination because they do not want to make their students uncomfortable. 
It is important to note that the distaste for critical modes of thought expressed by so many female interviewees may be misdirected contempt. Much of their discomfort was based on having observed hostile males in conversations or in classrooms. Indeed, casual observation confirms that in academic and social settings, men's behavior is typically more aggressive and bombastic than women's. Bellicose males, however, are not necessarily exemplary critical thinkers; they are just noisy. Critical thinking should not be confused with gratuitous aggression.

Thus, a recommendation to teach women uncritical thinking may be entirely unnecessary. Instead, a recommendation that pugnacious conversationalists and certain professors moderate their aggression might be a more appropriate inference from gender-related research programs. Certainly, demonstrating that critical thought and engaging conversation are not mutually exclusive is more beneficial than excusing the majority of women from the realms of critical thought. One of the essential steps in critical thinking is examining the assumptions or perspectives guiding behavior or arguments as a preliminary step toward evaluation. When one becomes "connected" in this way, the resulting evaluation is more fair. Connected knowing can, thereby, be a step toward better critical thinking.

Another recommendation made in Women's Ways of Knowing is that academics place more stress on personal experience as a basis for judgment. An over-emphasis on personal experience, in an effort to engage more women students in effective learning, could be a very limiting strategy, however. While personal experience can be extremely useful as a means of defining a particular idea or concept, heavy reliance on personal experience could be a great educational disservice to women. Thus, when women mention personal experience in class or in papers, they should not be denounced for lack of academic sophistication. Instead, they should be reminded that personal experience can deceive. Alerting students to the reality that personal experience can be a precarious compass by which to chart life is far more valuable than invariably accepting their personal experience as reliable evidence, even when that acceptance emanates from a desire to affirm rather than alienate.

Implying that critical thinking denies the necessity of understanding another's position is to attack a caricature of critical thinking. Female subjects in gender-related research studies convey an intense preference for understanding the other person's point of view. Critical thinking shares that desire. If one does not understand different sides of an issue, it is 
unlikely that the analysis of the issue will be worthwhile (Browne and Keeley, 1986; Meyers, 1986).

\section{Learning Styles Research}

Restricting critical thinking to a select body of students based on inferences from learning styles research can restrict students' development. While the intentions behind matching learning and teaching styles are noble, the wisdom of matching is easily exaggerated. In the extreme, matching could lead to complacency and stagnation among learners. Instructors' attempts to match teaching and learning styles could unnecessarily limit students' acquisition of other, perhaps temporarily uncomfortable, learning styles.

Clearly, clumsy mismatching may create even greater risks, but strategic mismatching, using critical thinking, deserves consideration (Doyle and Rutherford, 1984). Through selective mismatching, professors can equip students for a variety of learning styles that they are apt to encounter later in their educational experience: "Students will encounter professors who teach and test for comprehension and memorization or other styles. Accommodating a student's learning style might not serve him well when he is taught and tested using different styles" (Doyle and Rutherford, 1985).

Research advocating matching often relies heavily on the rationale that matching is conducive to academic success. But poorly specified dependent measures are common in such research. For example, improved scores on objective tests are repeatedly cited as evidence that matching positively affects students. Particular types of tests, however, tend to measure the success of one learning style more favorably than others. Thus, if professors encourage higher order thinking throughout the semester, but use objective tests, as opposed to essay tests, they are probably testing for a learning style they did not actively encourage. If the professor and the students have been matched for higher order thinking, such test results are ill-equipped to measure the relative success or failure of the match (Schmeck, 1981).

Any matching strategy that results in improved scores on objective tests provides strong evidence for benefits of matching only if we accept a definition of "success" that entails high scores on objective examinations. If, however, we decide that academic success is more appropriately defined as facility with complex, contemplative thought, many of the studies encouraging matching lack persuasive evidence. As Anthony Grasha (1984) perceptively notes, "To date, researchers have not 
delineated what constitutes content achievement, learner satisfaction, applications of content, abilities to think creatively, problem-solving or decision-making skills, self-concept, the types of learning methods used in continuing education, the quality of life for the learner and the instructor, or the motivation of people to pursue continuing education" (Grasha, 1984). In short, matching may or may not be desirable depending upon how dependent variables such as success and improvement are defined. Until more specific definitions are forthcoming, educators should proceed with caution prior to adopting matching strategies.

Determining the one "best" solution to teaching all levels of learning abilities in one classroom is difficult, if not impossible. Invariably, single solutions will benefit some at the expense of others (Good and Stipek, 1983). Instead of encouraging professors to match their teaching styles to the learning styles of their students, a more pragmatic approach would be to encourage professors to instruct in a way that encourages several styles, including critical thinking. Such intervention "will create a positive alignment of styles that will enable students to perform well. Also, such practices will better prepare students for other classes and improve the quality of teaching at the same time" (Ramsden, 1988). Such a strategy also circumvents boredom, a sure route to alienation in a classroom. Repetitive use of a single learning style is not conducive to effective pedagogy (Grasha, 1984).

Learning styles and gender-related research do deserve integration into classroom praxis. What they warrant, however, is a moderate approach that is cognizant of their potential misuse as well as of their advantages. A certain resignation characterizes much of the research on learning styles and gender. Rather than encouraging educators to intervene in students' educational experience, the recommendation is to accommodate. But educators should not fear motivating students toward change. Intervention, in an effort to encourage movement toward more complete appreciation of alternative ways of knowing, including critical thinking, is a crucial responsibility of educators. Students move from one level to another only with guidance and practice. Ideally, professors serve as bridges between levels. If the purpose of education were merely to reassure students that the level at which they are currently functioning is satisfactory, a university education would lose much of its potential as a stimulus for personal growth. 


\section{References}

Arlie, D. et al. (1984). Cognitive style as a predictor of achievement: A multivariate analysis. Paper presented at the Annual Convention of the International Communication Association, San Francisco, CA.

Association of American Colleges (1985). Integrity in the college curriculum. Washington, DC: Association of American Colleges.

Belenky, M.F., Clinchy, B.M., Golderger, N.R., \& Mattuck, J.T. (1986). Women's ways of knowing. New York: Basic Books.

Bristow, A., \& Esper, J. (1988). A feminist research ethos. In Nebraska Sociological Feminist Collective, A feminist ethic for social science research. Lewiston, New York: The Edwin Mellen Press.

Browne, M.N., \& Keeley, S.M. (1986). Asking the right questions: A guide to critical thinking. Englewood Cliffs, NJ: Prentice-Hall.

Charkins, R.J., O'Toole, D.M., \& Wetzel, J.N. (1985). Linking teacher and student learning styles with student achievement and attitudes. Joumal of Economic Education, 16, 111-120.

Claxton, C.S., \& Murrell, P.H. (1987). Learning styles: Implications for improving educational practices. Washington, DC: Association for the Study of Higher Education.

Clinchy, B.M. (1987). Separate and connected knowing and undergraduate teaching and learning. Paper presented at the University of Chicago Meeting on Critical Thinking and Context: Intellectual Development and Interpretive Communities, Chicago, IL.

Clinchy, B.M., \& Zimmerman, C. (1985). Connected and separate knowing. Paper presented at Symposium on Gender Differences in Intellectual Development: Women's Ways of Knowing at the Eighth Biennial Meeting of the International Society for the Study of Behavioral Development, Tours, France.

Doyle, W., \& Rutherford, B. (1984). Classroom research on matching learning and teaching styles. Theory Into Practice, 23, 20-25.

Dunn, R. (1988). Commentary: Teaching students through their perceptual strengths or preferences. Joumal of Reading, 31, 304-309.

Gilligan, C. (1987). In a different voice. In Bellah (Ed.), Individualism and commitment in American life. New York: Harper \& Rowe.

Good, T.L., \& Stipek, D.J. (1983). Individual differences in the classroom: A psychological perspective. In Fenstermache (Ed.), Individual differences and the common curriculum. Eighty-second yearbook of the national society for the study of education, Part I. Chicago: University of Chicago Press.

Grasha, A.F. (1984). Learning Styles: The journey from Greenwich Observatory (1796) to the college classroom (1984). Improving College and University Teaching, 32, 46-53.

Kohlberg, L. (1981). The philosophy of moral development. New York: Harper \& Row.

Malhotra, J. (1988). In Nebraska Sociological Feminist Collective, A feminist ethic for social science research. Lewiston, New York: The Edwin Mellen Press.

Meyers, C. (1986). Teaching students to think critically. San Francisco: Jossey-Bass. 
Miles, C. (1988). Cognitive learning strategies: Implications for college practice. In Weinstein et al., (Eds.), Learning and study strategies: Issues in assessment, instruction, and evaluation. San Diego: Academic Press, Inc.

National Institute of Education. (1984). Involvement in learning: Realizing the potential of American higher education. Washington, DC: National Endowment for the Humanities.

Paris, S.G. (1988). Models and metaphors of learning strategies. In Weinstein et al., (Eds.), Leaming and study strategies: Isoues in assessment, instruction, and evaluation. San Diego: Academic Press, Inc.

Pask, G. (1988). Learning strategies, teaching strategies, and conceptual or learning style. In Schmeck, R.R., (Ed.), Learning strategies and learning styles. New York: Plenum Press.

Piaget, J. (1948). The moral judgment of the child. New York: Free Press.

Radebaugh, M.R., Leach, J.N., Morrill, C., Shreeve, W., Slatton, S. (1988). Reading your professors: A survival skill. The Journal of Reading 31, 328-332.

Ramsden, P. (1988). Context and strategy: Situational influences on learning. In R.R. Schmeck (Ed.), Leaming strategies and leaming styles. New York: Plenum Press.

Schmeck, R.R. (1981). Improving learning by improving thinking. Educational Leadership, 38, 384-385.

Slocum, S. (1980). Woman the gatherer: Male bias in anthropology. In S. Ruth (Ed.), Issues in feminism (pp. 239-252). Boston: Houghton Mifflin.

Smith, D. (1974). Women's perspective as a radical critique of sociology. Sociological Inquiry, 44(1), 7-13.

Spender, D. (1981). The gatekeeper: A feminist critique of academic publishing. In $\mathbf{H}$. Roberts (Ed.), Doing feminist research. Boston: Routledge and Kegan Paul. 